\title{
DIVERGENTNÍ TRENDY V ZEMĚDĚLSTVÍ A V SEKTORU BIOPLYNOVÝCH STANIC V ČESKÉ REPUBLICE: P̌̌́lLĚ̆ITOST NEBO HROZBA?
}

\section{DIVERGENT TRENDS IN AGRICULTURE AND IN SECTOR OF ANAEROBIC DIGESTION PLANTS IN THE CZECH REPUBLIC: OPPORTUNITY OR THREAT?}

\author{
Mgr. Petr DVOŘÁK, Ph.D. ${ }^{1}$ \\ Mgr. Stanislav MARTINÁT ${ }^{1}$ \\ Mgr. Petr KLUSÁČEK, Ph.D. ${ }^{1}$ \\ DRs. DAN VAN DER HORST, PH.D. ${ }^{1}$ \\ RNDR. JoSEF NAVRÁTIL, PH.D. ${ }^{2}$ \\ Mgr. Marián KULLA, PH.D. ${ }^{3}$ \\ ${ }^{1}$ Oddělení environmentální geografie $\mid{ }^{1}$ Department of Environmental Geography \\ Ústav geoniky AV $\breve{C} R \quad$ Institute of Geonics, Academy of Sciences of the CR \\ $\triangle$ Studentská 1768, 70800 Ostrava, Czech Republic \\ E-mail:dvorak@geonika.cz,martinat@geonika.cz,klusacek@geonika.cz,d.vanderhorst@bham.ac.uk \\ ${ }^{2}$ Zemédělská fakulta ${ }^{2}$ Faculty of Agriculture \\ Jihočeská univerzita v Českých Budějovicich University of South Bohemia in České Budějovice \\ $\bowtie$ Studentská 13, 37005 České Budějovice, Czech Republic \\ E-mail:josefnav@gmail.com \\ ${ }^{3}$ Ústav geografie ${ }^{3}$ Department of Geography \\ Prírodovedecká fakulta Faculty of Science \\ Univerzita Pavla Jozefa Šafárika v Košiciach University of Pavol Jozef Safarik in Kosice \\ $\bowtie$ Jesenná 5, 04001 Košice, Slovak Republic \\ E-mailmarian.kulla@upjs.sk
}

\section{Anotace}

Obnovitelné zdroje energie a jejich podpora je v České republice široce diskutovaným tématem, které budi emoce na škále od souhlasu až po naprosté odmitání. Nicméně právě podpora z národnich $i$ evropských zdrojů je faktorem, který nejvýznamněji ovlivnil dynamický rozvoj tohoto sektoru v posledni dekádě. Bioplynové stanice jsou jednou z variant zařizení na výrobu obnovitelných zdrojů energie, která vedle solárních elektráren zaznamenala v poslednich letech nejvýznamnéjši růst svých kapacit. Předkládaný př́spěvek si klade za cíl nejprve analyzovat samotný fenomén bioplynových stanic, jeho legislativní, strategickou podporu, podpưrné finanční nástroje, jednotlivé typy stanic a dále analyzovat na základě dostupných statistických dat prostorové rozmistění jednoho z jejich typů, a to zemédělských bioplynových stanic. Na základě srovnání dat o bioplynu a dat o zemédělské výrobé jsou vyvozovány základni konsekvence mezi propady zemédělské výroby v regionech České republiky a nárůsty počtů a instalovaných výkonů zemédělských bioplynových stanic. Krátce je rovněž analyzována struktura osevních ploch a intenzita chovi hospodářských zvírat a jejich souvislosti s rozmistěním zemédělských bioplynových stanic. Lze konstatovat, že zemédělské bioplynové stanice
\end{abstract}


mají stále rostoucí vliv na strukturu osevních ploch zemědělství České republiky a jsou veřejností $i$ samotnými zemédělci více považovány za alternativni zdroj přijmů než př́spěvek $k$ ochraně životního prostředí, omezeni produkce skleníkových plynů a změně klimatu.

\section{Kličová slova}

bioplyn, zemédělství, Česká republika, prostorové rozmistění

\section{Annotation}

Renewable sources of energies and its support have been recently experiencing wide public debate in the Czech Republic that varies from agreement to complete denial. Nevertheless support from national and EU sources is factor that heavily influenced dynamic development of this sector in last decade. Anaerobic digestion plants are one of options for production of renewable energies that have experienced next to solar plants the most important increase of its installed capacities. This contribution aim to firstly analyse phenomenon of anaerobic digestion plants, its legal, strategic support, supporting financial incentives, individual types of such plants and secondly based on available statistical data analyse spatial distribution of agricultural anaerobic digestion plants. On basis of comparison of data for increasing biogas production and declining agriculture in regions of the Czech Republic basic consequence are deduced. In context of spatial distribution of agricultural anaerobic digestion plants structures of sowing areas and intensities of animal husbandry are shortly discussed. We can conclude that agricultural anaerobic digestion plants have been increasingly influencing structure of sowing areas of agriculture of the Czech Republic and such facilities are in both agricultural sector and wide society perceived more as alternative source of income than contribution to environment protection, limitations for greenhouse gases production and climate change.

\section{Key words}

biogas, agriculture, Czech Republic, spatial differentiation

JEL classification: $Q 2$

\section{Úvod}

Bioplynové stanice jsou v České republice fenoménem, který se v poslední dekádě stále více objevuje jak v urbánním, tak především v rurálním prostoru. Zatímco v roce 2002 bylo evidováno pouze 11 instalací bioplynových stanic s celkovým výkonem 4,19 MW, aktuálně (2013) je takovýchto instalací v České republice 481 o výkonu 363 MW. Nicméně v souvislosti se závazkem České republiky vůči Evropské unii, který do roku 2020 předpokládá minimálně $13 \%$ energie vyrobené z obnovitelných zdrojů (Národní plán na podporu obnovitelných zdrojů energie, 2010), lze očekávat další významný rozvoj tohoto sektoru energetiky. Aktuálně se bioplyn podílí na obnovitelných zdrojích energie 15,9\% (2013), do konce této dekády je předpokládán nárůst na $24 \%$ (cca $417 \mathrm{MW}$ ). Očekává se tedy, že počet bioplynových stanic bude $\mathrm{v}$ tomto časovém horizontu (do roku 2020) pravděpodobně zvýšen o přibližně 60-80 stanic a instalovaný výkon o dalších cca $15 \%$ oproti dnešnímu stavu. Je však otázkou, jakým způsobem a jakými prostředky či nástroji, prostřednictvím jakých kroků je možné, či lépe řečeno vhodné, rozmístění i vlastní fungování bioplynových stanic či jejich parametry regulovat.

Tento př́spěvek si klade za cíl nejprve analyzovat samotný fenomén bioplynových stanic, jeho legislativní, strategickou podporu, podpůrné finanční nástroje, jednotlivé typy stanic a dále analyzovat na základě dostupných statistických dat prostorové rozmístění jednoho z jejich typů, a to zemědělských bioplynových stanic. Na základě srovnání dat o bioplynu a dat o zemědělské výrobě jsou vyvozovány základní konsekvence mezi propady zemědělské výroby v regionech České republiky a nárůsty počtů a instalovaných výkonů zemědělských bioplynových stanic. Krátce je rovněž analyzována struktura osevních ploch a intenzita chovů hospodářských zviŕat a jejich souvislosti s rozmístěním zemědělských bioplynových stanic. 


\section{Legislativní a strategické předpoklady pro rozvoj bioplynového sektoru}

Legislativní a strategická opatření jsou základními předpoklady, jimiž je formován rozvoj obnovitelných zdrojů v České republice. Právní úprava v oblasti energetiky je v České republice tvořena třemi hlavními zákonnými předpisy - Zákonem č. 458/2000 Sb., o podmínkách podnikání a výkonu státní správy $\mathrm{v}$ energetických odvětvích (též energetický zákon), který upravuje základní podmínky pro podnikání a státní regulaci v elektroenergetice, plynárenství a teplárenství. Kromě jiného se zabývá také licencemi pro výrobu elektřiny a zakotvuje právo přednostního připojení výrobců elektrické energie a tepla z obnovitelných zdrojů $\mathrm{k}$ distribuční síti. Dále jde o Zákon č. 406/2000 Sb., o hospodaření energií, jež určuje pravidla pro efektivní a šetrné využívání energií a energetických zdrojů.

Důležitým mezníkem pro historii podpory obnovitelných zdrojů v České republice bylo vydání Zákona č. 180/2005 Sb., o podpoře výroby elektřiny z obnovitelných zdrojů energie (zákon o podpoře využívání obnovitelných zdrojů), který upravuje v souladu se Směrnicí EU č. 2001/77/ES způsob podpory výroby elektřiny z obnovitelných zdrojů, nebot' mezi jeho základní cíle patřilo zvýšit podíl obnovitelných zdrojů na hrubé spotřebě elektrické energie v Č́R na $8 \%$ k roku 2010 , což se díky boomu solární energetiky podařilo, a vytvořit podmínky pro další zvyšování tohoto podílu po roce 2010 (viz výše). Zákon stanovil povinnost provozovatelů přenosových, soustav přednostně připojit výrobce elektřiny z obnovitelných zdrojů, kteří splňují podmínky stanovené energetickým zákonem. Zákon se také věnoval problematice podpory obnovitelných zdrojů prostřednictvím výkupních cen elektřiny a zelených bonusů, které pak každoročně na základě svého cenového rozhodnutí vyhlašuje Energetický regulační úřad (ERÚ).

Tento zákon byl k 1. lednu 2013 nahrazen Zákonem č. 165/2012 Sb., o podporovaných zdrojích energie, který ho komplexně novelizuje. V tomto př́ípadě šlo o reakci na Směrnici EU č. 2009/28/ES a z ní vzešlý Národní akční plán pro obnovitelné zdroje energie v České republice z roku 2010. Mezi základní cíle tohoto zákona patř́ zvýšit podíl obnovitelných zdrojů na hrubé spotřebě energie v ČR na $13,5 \% \mathrm{k}$ roku 2020, nicméně současně má „zohlednit zájmy zákazníků na minimalizaci dopadů podpory obnovitelných zdrojů na ceny energií pro zákazníky v ČR" ( 11 odstavec 2 písmeno d zákona č. 165/2012 Sb.). Má tak v podstatě zamezit dalšímu nekontrolovatelnému růstu obnovitelných zdrojů a tím i objemu jeho finanční podpory, nebot' ten je součástí ceny elektrické energie pro koncového zákazníka a neúměrně roste. Tento cíl je naplněn navázáním podpory výkupních cen pro obnovitelné zdroje energie na cíle Národního akčního plánu pro obnovitelné zdroje energie (2010), který vyčísluje instalovaný výkon jednotlivých druhů obnovitelných zdrojů pro každý rok na období let 2010-2020. Při dosažení tohoto ročního cíle nebude již zákonná povinnost nové zdroje podporovat formou výkupních cen, či zeleného bonusu.

\section{Podpora bioplynových stanic}

Podpora výroby bioplynu jako obnovitelného zdroje energie je v podmínkách České republiky realizována dvojím způsobem. Jednak podporou samotné výstavby bioplynových stanic, jednak zajištěním výkupu elektrické energie, př́padně podporou kombinované výroby elektřiny a tepla prostřednictvím garantovaných výkupních cen a zelených bonusů (tzv. feed-in tariff). Podpora produkce bioplynu prostřednictvím feed-in tariffủ je v České republice nastavena od roku 2002. Každoročně je revidována, platí $\mathrm{v}$ daném roce pouze pro nové instalace, dř́vějším zdrojům je pak jejich původní výkupní cena valorizována. Od roku 2006, kdy vstoupil v platnost zákon č. 180/2005 Sb. je pak garantována i patnáctiletá návratnost investic do výstavby bioplynové stanice. Podporované výkupní ceny elektrické energie a zelené bonusy pro zemědělské bioplynové stanice, které uvádí graf 1, nezaznamenaly tak významnou dynamiku jako u solární energetiky, jsou od roku $2009 \mathrm{v}$ celku stabilní a činí 4120 Kč za 1MWh elektrické energie. Pouze v roce 2012 došlo ke snížení podpory pro bioplynové stanice, které nesplňovaly dodatečné kritérium, a to využívání alespoň $10 \%$ tepla produkovaného v bioplynových stanicích jako vedlejší produkt při výrobě bioplynu. Tyto bioplynové stanice se tak svou podporou dostaly na úroveň bioplynových stanic zpracovávajících odpady 
(výkupní ceny elektrické energie $3550 \mathrm{Kč} / \mathrm{MWh}$ a zelený bonus $2500 \mathrm{Kč} / \mathrm{MWh}$ ), která je obecně v českých podmínkách nižší.

Graf 1: Vývoj výkupních cen elektrické energie a zelených bonusů pro zemědělské bioplynové stanice v České republice v období 2005-2012 (v Ǩ̆/MWh).

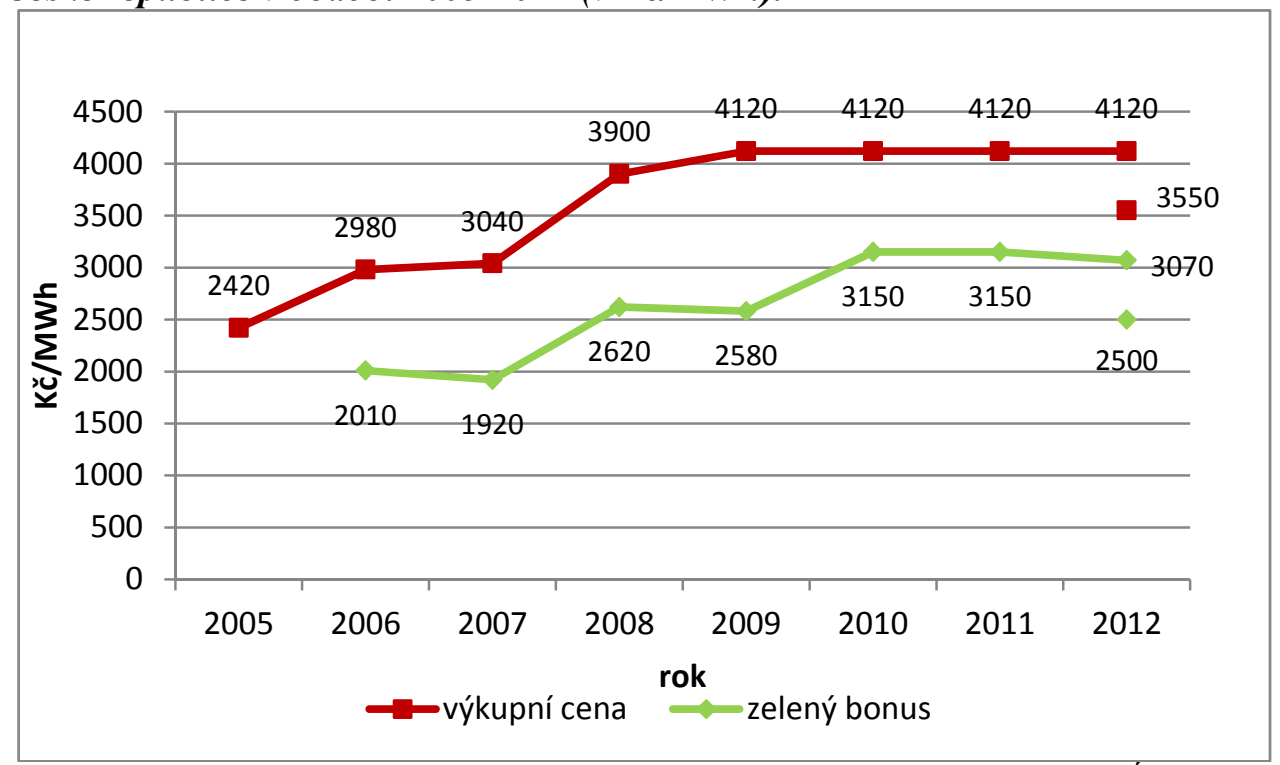

Zdroj: Energetický regulační úřad (ERÚ), vlastní zpracování

Průměrné investiční náklady bioplynové stanice, které ve své studii uvádí Dvořáček (2009), se pohybují pro zemědělské bioplynové stanice $\mathrm{v}$ hodnotě přibližně 100 tisíc $\mathrm{Kč} / \mathrm{kW}$ instalovaného výkonu. V prŕípadě bioplynové stanice zaměřené na zpracování odpadů jde o částku v rozmezí 200250 tisíc $\mathrm{Kč} / \mathrm{kW}$. Jejich rozdílná výše je dána odlišným charakterem použité technologie a zpracovávaných surovin a obecně i zde platí ekonomický koncept úspor z rozsahu (economies of scale - viz např. Krugman, 1980), kde platí, že čím má bioplynová stanice nižší instalovaný výkon, tím vyšší jsou investiční náklady na jednotku kW.

Výstavba většiny provozovaných bioplynových stanic byla $\mathrm{v}$ České republice spolufinancována z veřejných zdrojů. Hlavními zdroji byly prostředky z Programu rozvoje venkova České republiky pod gescí Ministerstva zemědělství, dále pak Operační program Životní prostředí - prioritní osy 3: Udržitelné využívání zdrojů energie (Ministerstvo životního prostředí) a Operační program Podnikání a inovace - prioritní osa 3: Efektivní energie (Ministerstvo průmyslu a obchodu). Význam subvencí pro bioplynový sektor je dobře patrný i z grafu 2 , kde první výraznější nárůst počtu stanic spadá do roku 2008, tedy do období realizace schválených projektů na výstavbu bioplynových stanic z první výzvy Programu rozvoje venkova. Celkem bylo do roku 2012 z tohoto programu podpořeno 178 projektů částkou 3,147 miliard Kč (Diverzifikace činností nezemědělské povahy III.1.1.b, Podpora zakládání podniků a jejich rozvoje III.1.2.b), přičemž maximální výše podpory byla stanovena na 40 až $60 \%$ podle velikosti podniku žadatele (Program rozvoje venkova České republiky na období 2007 - 2013, 2010). Průměrná výše dotace na jednu bioplynovou stanici zemědělského typu činila 17,7 milionu Kč. Z Operačního programu Životní prostředí bylo podpořeno 6 projektů za 142 milionů Kč., z Operačního programu Podnikání a inovace 35 projektů částkou 520 mil Kč (podpořeny byly projekty jak zemědělských, tak i odpadových bioplynových stanic), celkem šlo tedy o více než 3,8 miliardy Kč za všechny uvedené bioplynové zdroje celkem. Je možné konstatovat, že většina zmíněných podpor byla investována $\mathrm{v}$ zemědělských bioplynových stanicích, $\mathrm{v}$ prrípadě ostatních typů bioplynových stanic (viz níže) nejsou takové podpory př́iliš obvyklé. 
Graf 2: Vývoj instalovaného výkonu a počtu bioplynových stanic v České republice v období 20022013

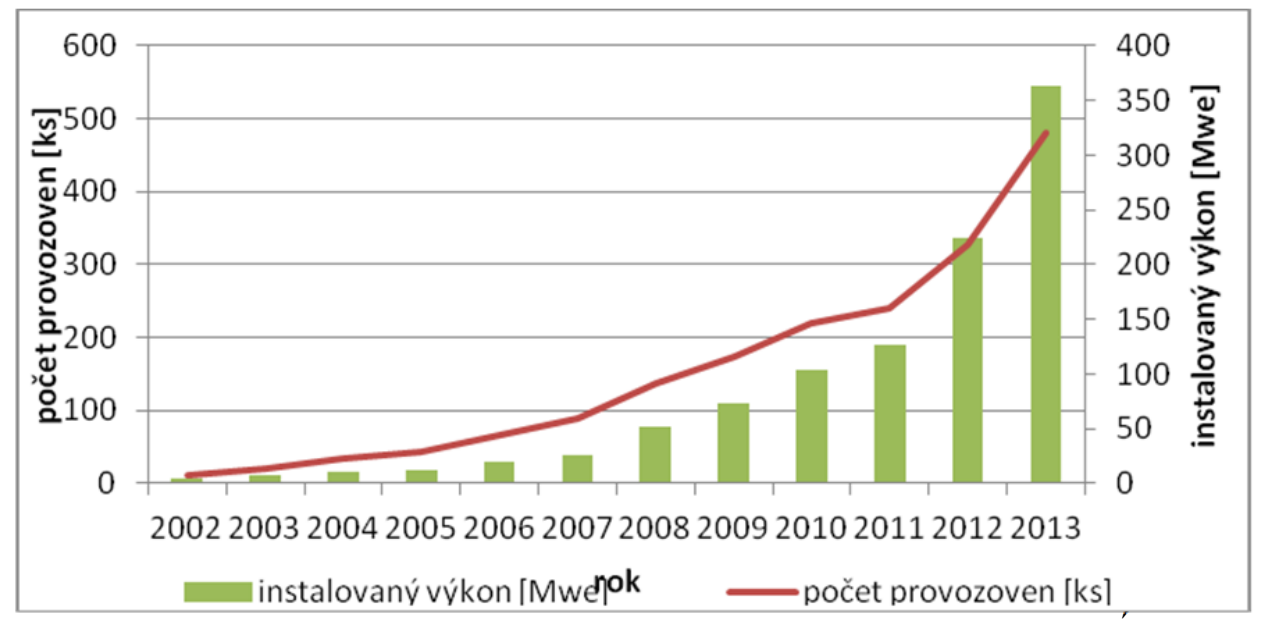

Zdroj: Energetický regulačni úr̆ad (ERÚ), vlastni zpracování

Zemědělské bioplynové stanice, kterým se $\mathrm{v}$ dalším textu budeme převážně věnovat, zpracovávají cíleně pěstovanou rostlinnou biomasu (kukurrici na zeleno, trávu, víceleté pícniny atd.) a vedlejší produkty živočišné výroby (kejda, hnůj, atp.). Stabilizovaný fermentační zbytek, tzv. digestát, je pak možno využít jako hnojivo (Marada et al., 2008). Prostorové rozmístění bioplynových stanic v České republice ilustruje obrázek 1. Vedle již uvedeného typu zemědělských bioplynových stanic jsou zde uvedeny i bioplynové stanice zpracovávající průmyslové a komunální odpady (červeně), stanice umístěné na čističkách odpadních vod (zejména v urbánním prostoru - modře) a stanice, které fungují na skládkách a využívají tzv. skládkový plyn (žlutě).

\section{Obr. 1: Prostorové rozmistění základních typů bioplynových stanic v České republice (2012)}

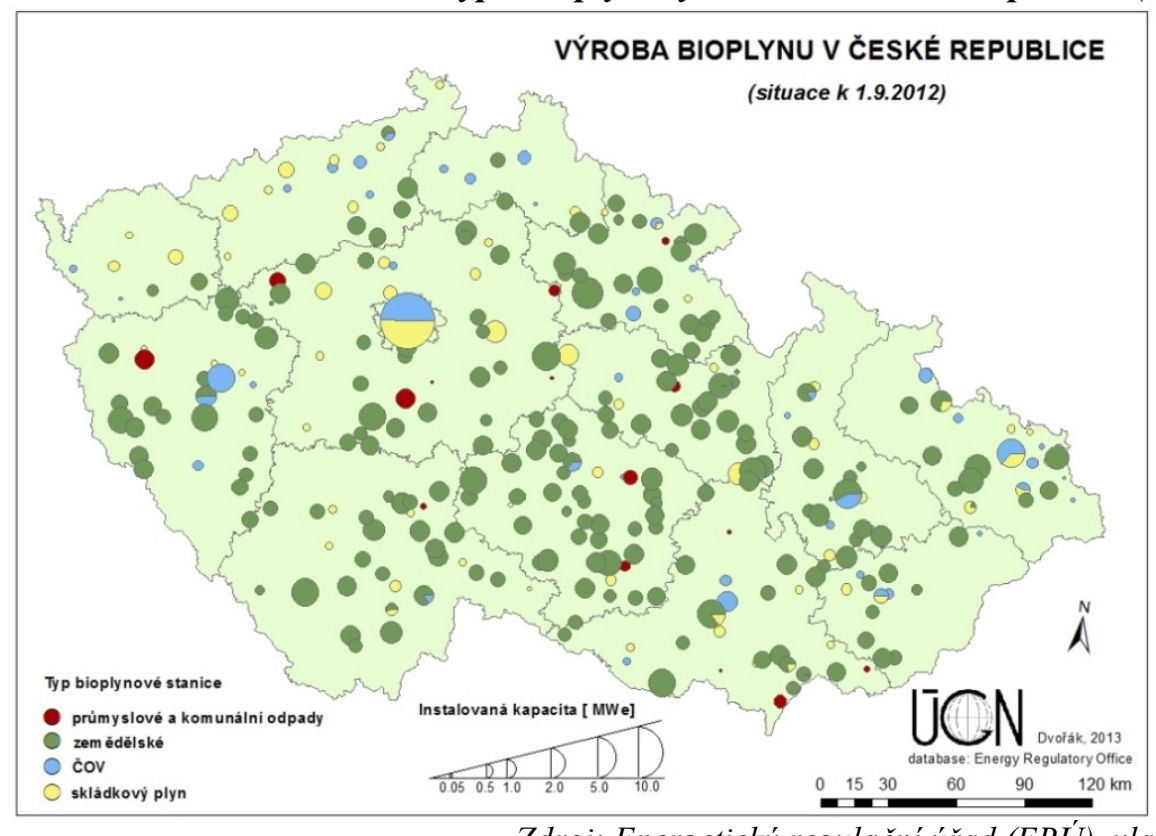

Zdroj: Energetický regulační úŕad (ERÚ), vlastní zpracování

\section{Propad zemědělství}

V další kapitole se zabýváme především zemědělskými bioplynovými stanicemi. Cílem je stručně analyzovat konsekvence mezi propady zemědělské výroby v regionech České republiky a nárůsty počtů zemědělských bioplynových stanic. 
Zemědělství České republiky prošlo v posledních dvou dekádách dramatickými strukturálními proměnami. Centrálně plánovaná zemědělská politika, která majoritně ovlivňovala produkční a organizační strukturu zemědělství tehdejšího Československa, byla od počátků 90 . let 20. století opouštěna ve prospěch liberalizace, uvolňování celních bariér a umožnění vyšší míry zemědělských a potravinářských importů do České republiky. Procesy jako privatizace (převod majetku do soukromých rukou) a restituce (navracení majetků původním majitelům) zemědělských pozemků či objektů hluboce ovlivnily rozsah i strukturu zemědělské výroby v České republice. Od počátků nového tisíciletí začíná být nejvlivnější faktorem ovlivňujícím české zemědělství Společná zemědělská politika Evropské unie, nejdřive ve formě předstupních programů, po vstupu země do Evropské unie (2004) její standardní aplikací (Věžník a Konečný, 2011). Propady zemědělství České republiky i proměny jeho organizační struktury jsou regionálně diferencovány v závislosti na přirodních podmínkách a historických předpokladech zemědělského využívání daného území (Martinát et al., 2009).

Bereme-li v úvahu zemědělský sektor České republiky jako celek, pak za dvě dekády od roku 1990 poklesla jeho hrubá zemědělská produkce o $31 \%$ na 17,4 tisíc Kč (na 1 hektar zemědělské půdy ve stálých cenách roku 1989), došlo k omezení počtu skotu o $61 \%$, počtu prasat o $67 \%$, poklesly také osevní plochy klasických plodin, jako jsou napríklad brambory a narostly osevní plochy plodin využívaných pro energetiku. Ve stejném období se spotřeba potravin v České republice nijak výrazně nepropadla, tudíž velká část domácí spotřeby je kryta importy potravin ze států EU i mimo ni. V souvislosti s poklesem českého zemědělství se ve venkovském prostoru objevuje řada nevyužívaných objektů a areálů, často kontaminovaných, které označujeme jako plochy brownfields (Svobodová a Věžník, 2009, Navrátil et al. 2010, Klusáček et al., 2011, 2013). Stále intenzivněji jsou zemědělci nuceni provozovat alternativní zemědělské či nezemědělské aktivity, které tvoři stále se zvyšující podíl jejich př́imů. Tedy od pěstování alternativních plodin, provozování ekologického zemědělství (např. Ilbery a Maye, 2011), zpracování a prodej produktů přímo na farmě, přes aktivity v cestovním ruchu (např. Navrátil et al., 2009) jako př́kladu nezemědělských aktivit až po nepotravinářské využívání zemědělské půdy. Př́íkladem posledního typu je využívání půdy pro pěstování zemědělských plodin pro energetické účely (napřs. řepka olejná) či plodin prŕmo pro bioplynové stanice (kukuřice na zeleno, pícniny atd.).

Informaci o dynamice, s jakou se od roku 2006 šíríly zemědělské stanice ve venkovském prostoru České republiky, podává obrázek 2. Je samozřejmě nezbytné konstatovat, že stěžejním předpokladem pro tak výrazný nárůst počtu bioplynových stanic, je subvenční politika státu a Evropské unie. Stanice, které by vznikaly bez podpory, jsou spíše výjimkou (jde např́klad o bioplynovou stanici v Palkovicích v Moravskoslezském kraji či obci Lípa v kraji Vysočina - Trnavský, 2012). V př́padě ostatních typů bioplynových stanic jsou tyto případy $\mathrm{v}$ naprosté většině. Nicméně zmíněné prríklady naznačují, že bioplynovou stanici je možné vybudovat i bez dotačních zdrojů. Z historického úhlu pohledu jsou počátky bioplynových stanic na území České republiky kladeny do poloviny 70 . let 20 . století, kdy byla vybudována bioplynová stanice $\mathrm{v}$ Třeboni, a to na místní čistírně odpadních vod, kam byla dodávána i kejda prasat z blízkých velkokapacitních vepř́nů (o kapacitě cca 30 tisíc kusů prasat). V tomto období však byla takováto forma zpracovávání zemědělských odpadů považována spíše za experiment.

Navázat se podařilo o 30 let později, nicméně ještě v roce 2006 bylo v České republice provozu pouze 6 zemědělských bioplynových stanic, z nichž pouze dvě měly instalovaný výkon vyšší než $1 \mathrm{MW}$ (bioplynová stanice ve Velkém Karlově v Jihomoravském kraji a v Klokočově v okrese Opava). Regiony, kde je bioplynových stanic aktuálně nejméně, jsou kraje Karlovský (instalovaný výkon 1,1 MWh), Liberecký (1,6 MWh), Ústecký (3,7 MWh) a naopak kraji s nejvyšším počtem zemědělských bioplynových stanic je Vysočina (30,8 MWh) spolu s Jihočeským (20,2 MWh) a Pardubickým krajem $(19,1 \quad M W h)$. Největší instalovaný výkon evidujeme $\mathrm{v}$ př́padě bioplynové stanice v Královehradeckém kraji, konkrétně v obci Králíky, a to 2,5 MWh.

Jak napovídá obrázek 2, stěžejním faktorem ovlivňujícím rozmístění zemědělských bioplynových stanic v České republice, jsou přírodní podmínky pro zemědělské hospodaření. Dále lze diskutovat o 
významu míry akceptace jednotlivých projektů stanic na regionální (odvolací orgány v př́ípadě stížností) i lokální úrovni (místní obyvatelstvo), ale i o míře podnikatelské aktivity zemědělců v jednotlivých regionech. Svůj význam mají rovněž i př́íklady dobré praxe bioplynových stanic (Stonava v Moravskoslezském kraji, Třeboň v Jihočeském kraji, Letohrad v Pardubickém kraji). Zde je šíření tohoto typu obnovitelných zdrojů intenzivnější (kraj Vysočina, Jihočeský kraj). Pohlédnemeli na problematiku $z$ opačného úhlu pohledu, tedy př́kladů špatné praxe, pak je tento jev patrný zejména $\mathrm{v}$ oblastech, kde mají bioplynové stanice problémy se svým provozem (technologické potíže a související zápach atd.) a jeho vlivy na kvalitu života $\mathrm{v}$ dané obci. Jako jistý typ př́íkladu špatné praxe např́klad na území Jihomoravského kraje slouži bioplynová stanice ve Velkém Karlově, o čemž svědčí i zprávy publikované lokálními médii (viz napřr. tisková zpráva České inspekce životního prostředí - Bioplynová stanice Velký Karlov zaplatí pokutu 5 milionů z roku 2009; či zprávy z lokálních médií - Kdo zastaví bioplynku ve Velkém Karlově z roku 2010; Bioplynová stanice u Znojma nebude, pomohla petice z roku 2012). Relativně vyšší shluky zemědělských bioplynových stanic nalézáme spíše $\mathrm{v}$ periferních rurálních polohách s podprůměrnými př́rodními podmínkami pro klasické zemědělství (např́klad pás táhnoucí se od jihozápadu Českomoravskou vrchovinou na severovýchodu do podhůří Orlických hor či oblast podhưří Českého lesa v západních Čechách). Rovněž je na zvýšený výskyt bioplynových stanic patrný vliv mezikrajských periferních poloh na hranicích mezi Středočeským a okolními kraji (s vyšší intenzitou na severu, západě, méně na jihu). V př́padě Středočeského kraje lze dát daný fakt do souvislosti se širokým suburbánním prstencem obcí okolo hlavního města, kde je možnou bariérou nově přistěhovalé obyvatelstvo.

Obr. 2: Dynamika rưstu počtu a instalovaného výkonu zemědĕlských bioplynových stanic v České republice (2006, 2008, 2010, 2012)

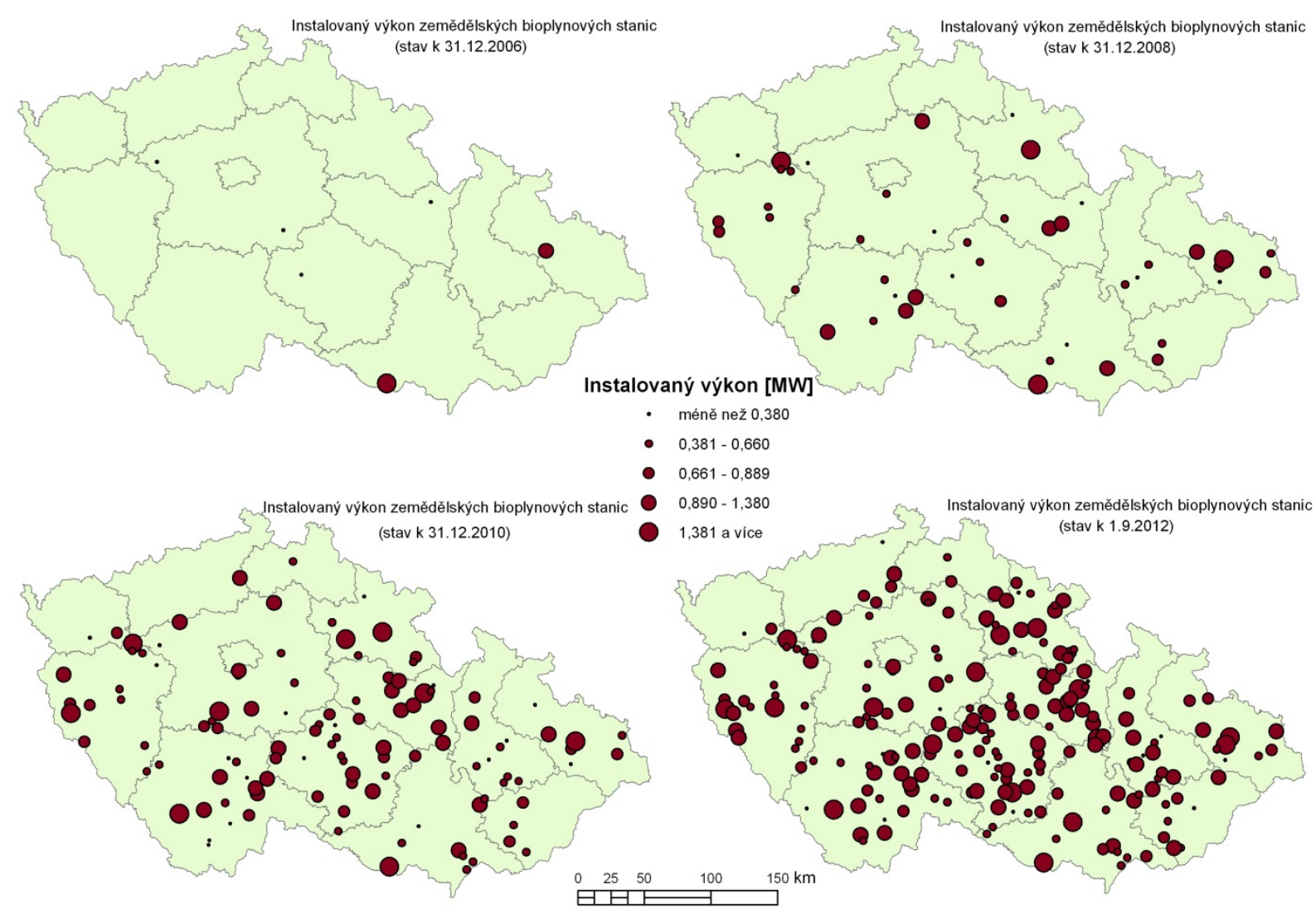

Zdroj: Energetický regulačni úr̆ad (ERÚ), vlastní zpracování

Zemědělské bioplynové stanice byly hodnoceny i v souvislosti se zaměřením jednotlivých okresů, v nichž jsou lokalizovány, na produkci konkrétních zemědělských plodin a chov hospodářských zviřrat. Základním východiskem zde byl předpoklad, že větší počet bioplynových stanic s vyšším instalovaným výkonem $\mathrm{v}$ okrese, se musí odrážet i ve struktuře osevních ploch a intenzitě chovu hospodářských zvířat. Byly hodnoceny osevní plochy řady zemědělských plodin, nicméně s ohledem 
na nejčastěji využívané vstupy do bioplynových stanic, byly podrobněji analyzovány zejména osevní plochy kukuřice na zeleno, jednotlivých typů pícnin, dále intenzita chovu skotu (viz obrázek 3) či prasat a drůbeže.

\section{Obr. 3: Intenzita zemědělské výroby (chov skotu, kukuřice na zeleno) a prostorové rozmístění zemědělských bioplynových stanic}

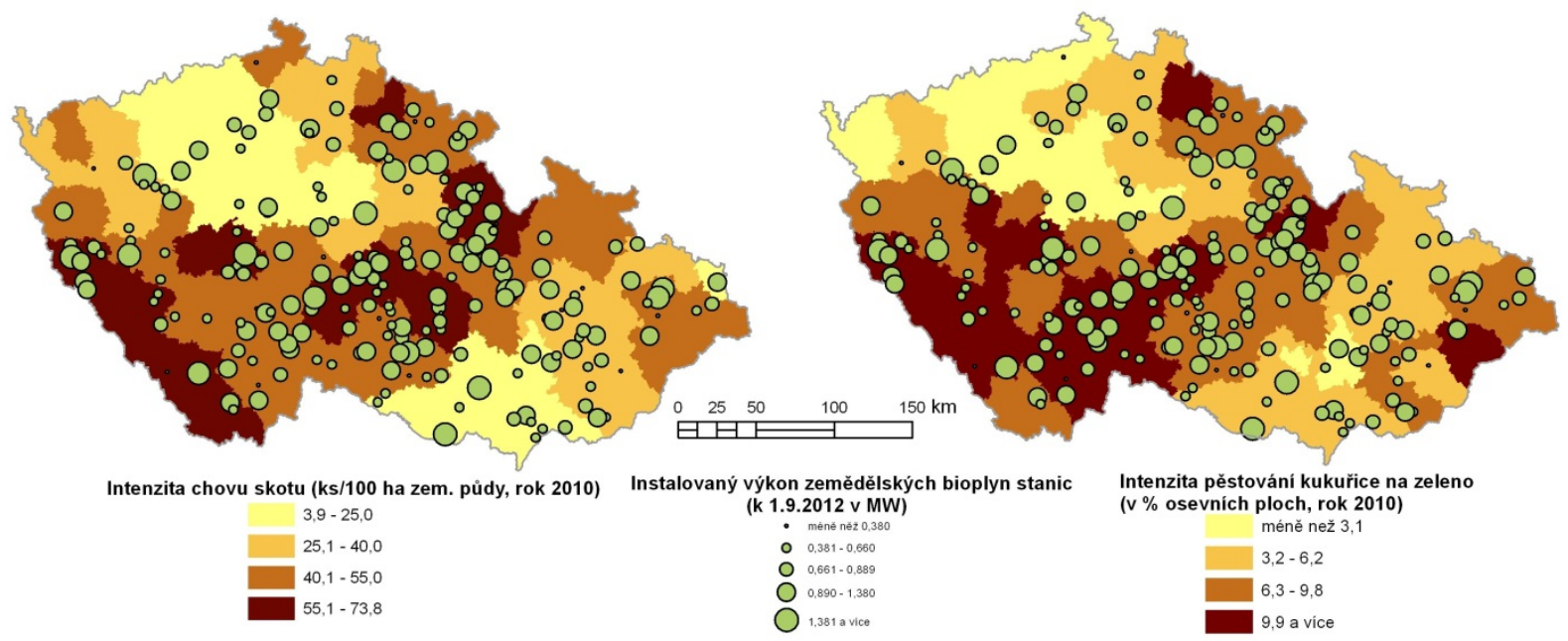

Zdroj: Energetický regulačni úrad (ERÚ), vlastni zpracováni

Lze konstatovat, že zvýšené podíly osevních ploch kukuřice na zeleno, ale také zvýšené intenzity chovu skotu, korelovaly s územími, kde je koncentrován vyšší počet zemědělských bioplynových stanic. V př́ipadě kukư̌ice na zeleno šlo o pás území od Šumavy přes Jihočeské pánve $\mathrm{k}$ Českomoravské vrchovině a dále na sever k podhưří Orlických a Jizerských hor. V případě souvislostí s intenzitami chovu skotu šlo o obdobná území.

S ohledem na energetický potenciál zmíněných vstupů je zarážející relativně nízká korelace výskytu bioplynových stanic s intenzitou chovu drůbeže, nebot' drůbeží kejda má mnohem (až 4x) vyšší energetickou výtěžnost, než skot. Vysokým energetickým potenciálem rovněž disponují obilniny, či řepka olejná (až 3x více než kukuřice na zeleno). Naopak nejnižší energetický potenciál je udáván pro odpady z chovů prasat, a to až o polovinu méně než v př́ípadě skotu (Banks et al., 2006).

\section{Závěr}

Do roku 2020 je ve venkovském prostoru České republiky očekáváno další rozšiřování sektoru zemědělských bioplynových stanic. Lze předpokládat, že instalovaný výkon stanic naroste o cca $15 \%$ (na $417 \mathrm{MW}$ ) a jejich počet se na konci této dekády ustálí na přibližně 550 . Je nepochybné, že bioplynové stanice mají své ekonomické, sociální i environmentální konsekvence, které se projevují zejména $\mathrm{v}$ místě (obci), kde jsou takovéto provozy lokalizovány ( $\mathrm{k}$ tématu se $\mathrm{v}$ obecné rovině vyjadřují např. také Van der Horst, 2009, Frantál a Kučera, 2009 či Frantál a Kunc 2010, 2011). Tyto konsekvence mohou být jak pozitivní (zvýšení či udržení počtu pracovních př́iležitostí v obci, zvýšení a stabilizace př́imů pro zemědělce, využití odpadů ze zemědělské výroby, vhodná likvidace nepotřebné senáže, likvidace posečené trávy z obecních pozemků, možné zpracování bioodpadů z domácností, snížení závislosti na fosilních palivech, možné využití potenciálu tepla, využití digestátu jako hnojiva, snížení emisí $\mathrm{CO}_{2}$ atd.), tak i negativní (využívání zemědělských plodin pro energetiku, závislost na dotacích, administrativní zátěž, ovlivnění kvality života v obci - možný zápach a zvýšená doprava $\mathrm{v}$ obci, etický problém při využivání půdy pro nepotravinářské účely, možné snížení atraktivity obce atd.).

Rozhodujícím faktorem, který ovlivňuje rozvoj sektoru bioplynových stanic, je dotační politika státu a Evropské unie. Podporu je možné získat jak na samotnou investici, tak i na provoz stanice ve formě 
garantovaného výkupu vyrobené elektrické energie. A právě prostřednictvím dotací lze dosáhnout takové regulace odvětví bioplynových stanic, která by vyhovovala nejen nezbytnosti zvýšení př́ijmů zemědělcům (což je v současné době hlavním cílem podpůrných programů), ale také aby koncepčněji působila ve prospěch životního prostředí. Lze diskutovat o provázání dotací s povinností využívat ve větší míře odpadní teplo, více regulovat možné vstupy do bioplynových stanic s cílem omezení využívání kukuřice, zvýšit míru využivání zemědělských odpadů, ale i bioodpadů z domácností, provázat dotace s provozováním vlastních chovů hospodářských zviŕrat atd. - viz např. Hlaváček, et al., 2012).

Z výše uvedených analýz vyplývá, že se zemědělské bioplynové stanice staly ve venkovském prostoru České republiky výrazným fenoménem, který významně ovlivňuje i strukturu osevních ploch (nárůsty ploch plodin, kterou jsou využívány jako vstupy do bioplynových stanic). Na druhou stranu dramatické propady počtů a intenzit chovů hospodářských zviŕat v posledních letech (počet prasat např́klad poklesl oproti roku 2004 o téměř 50 \%) lze chápat také jako jistý typ ohrožení vstupů do bioplynových stanic. Soužití bioplynových stanic a zemědělství se na první pohled zdá jako oboustranně výhodný vztah. Zemědělství, které obtížně hledá odbyt pro své produkty na českém trhu přesyceném levnými importy, je nalézá v bioplynových stanicích. Naopak bioplynové stanice slouží zemědělcům jako alternativní zdroj př́immů, jímž financují i ostatní aktivity, které v současných podmínkách nejsou př́liš tržně rentabilní (chov prasat, skotu atd.). Nicméně výše zmíněná výhodnost vztahu zemědělství a sektoru bioplynových stanic má své slabiny. Jednak využívání zemědělské půdy pro nepotravinářské účely budí časté kontroverze mezi veřejností, ale i mezi samotnými zemědělci, jednak z pohledu životního prostředí by bylo mnohem užitečnějš́í, kdyby byly bioplynové stanice intenzivněji specializovány na energetické zpracování bioodpadů at' už z vlastního zemědělského hospodaření, z domácností v lokalitě či blízkém okolí, prřípadně zpracování trávy, což jsou produkty, jejichž nepochybný potenciál zůstává z velké části stále mimo pozornost.

\section{Literatura}

[1] BANKS, C. J., SALTER, A. M., CHESSHIRE, M. Potential of anaerobic digestion for mitigation of greenhouse gas emissions and production of renewable energy from agriculture: barriers and incentives to widespread adoption in Europe. Problems in Agro-Industries, 7th Symposium on Waste Management, Amsterodam, September 27-29, 2006.

[2] DVOŘÁČEK, T. Ekonomika bioplynových stanic pro zpracování BRO. Biom.cz [online]. 2010. [cit. 2013-04-25]. Dostupné z: <http://biom.cz/cz/odborne-clanky/ekonomika-bioplynovychstanic-pro-zpracovani-bro>.

[3] FRANTÁL, B., KUČERA, P. Impacts of the operation of wind turbines as perceived by residents in concerned areas. Moravian Geographical Reports, 2009, 17, 2: 35-45.

[4] FRANTÁL, B., KUNC, J. Factors of the uneven regional development of wind energy projects (a case of the Czech Republic). Geografický Časopis / Geographical Journal, 2010, 62, 3: 183201.

[5] FRANTÁL, B., KUNC, B. Wind turbines in tourist landscape: Czech experience. Annals of Tourism Research, 2011, 38, 2: 499-519.

[6] HLAVÁČEK, M., DOUCHA, T., FIALKA, J., BEČVÁŘOVÁ, V., ČECHURA, L., ECK, V., SEKÁČ, P., BENEŠ ŠPALKOVÁ, J., JÍLEK, P., KREUTZER, T. Strategie pro ruist. České zemédělstvi a potravinářrstvi v rámci Společné zemédělské politiky EU po roce 2013. Praha> Ministerstvo zemědělství ČR, 2012, 64.

[7] ILBERY, B., MAYE, D. Clustering and the spatial distribution of organic farming in England and Wales. Area, 2011, 43, 1:31-41.

[8] KLUSÁČEK, P., KREJČÍ, T., KUNC, J., MARTINÁT, S., NOVÁKOVÁ, E. The post-industrial landscape in relation to local self-government in the Czech Republic. Moravian Geographical Reports, 2011, 19, 4: 12-28.

[9] KLUSÁČEK, P., KREJČÍ, T., MARTINÁT, S., KUNC, J., OSMAN, R., FRANTÁL, B. Regeneration of agricultural brownfields in the Czech Republic - Case study of the South Moravian Region. Acta Universitatis Agriculturae et Silviculturae Mendelianae Brunensis, 2013, 61, 2: 549—561. 
[10] KRUGMAN, P. Scale Economies, Product Differentiation, and the Pattern of Trade. The American Economic Review, 1980, 70, 5, 950-959.

[11] MARADA, P., VEČEŘOVÁ, V., KAMARÁD, L., DUNDÁlKOVÁ, P., MAREČEK, J. Př́ručka pro nakládání s digestátem a fugátem. Brno: Mendelova univerzita v Brně, 2008, 30.

[12] MARTINÁT, S., KLAPKA, P., NOVÁKOVÁ, E. Changes of spatial differentiation in livestock breeding in the Czech Republic after 1990. Rural Studies (PAN Warszawa), 2008, 15: 97-120.

[13] Národní akčni plán České republiky pro energii z obnovitelných zdrojů. Praha: Ministerstvo průmyslu a obchodu ČR, 2010, 97.

[14] NAVRÁTIL, J., MARTINÁT, S., KALLABOVÁ, E. Perception of angling as tourist attractivity in South Bohemian Basin. Agricultural Economics - Czech, 2009, 55, 10: 508-518.

[15] NAVRÁTIL, J., PÍCHA, K., HŘEBCOVÁ, J. The importance of historical monuments for domestics tourists: The case of South- Western Bohemia (Czech Republic). Moravian Geographical Reports, 2010, 18, 1: 45-61.

[16] Program rozvoje venkova České republiky na obdobi 2007 - 2013. Praha: Ministerstvo zemědělství ČR, 2010, 221.

[17] SVOBODOVÁ, H., VĚŽNÍK, A. To the problems of agricultural brownfields in the Czech Republic, case study of the Vysocina Region. Agricultural Economics - Czech, 2009, 55, 11: 550-556.

[18] Van DER HORST D. Spatial planning of wind turbines and the limits of 'objective' science. Moravian Geographical Reports, 2009, 17, 2: 46-51.

[19] TRNAVSKÝ, J. Bioplynové stanice jsou efektivní i bez dotace. Energie, 2011, 21, 6.

[20] VĚŽNÍK, A., KONEČNÝ, O. Agriculture of the Czech Republic after Accession to the EU: Regional Differentiation. Moravian Geographical Reports, 2011, 19, 1: 50-60.

Př́spěvek byl zpracován v rámci projektu OPVK pod názvem „Energetika v krajině: inovace, dynamizace a internacionalizace výzkumu" (CZ.1.07/2.3.00/20.0025). 